\title{
The Links between Unemployment and Self- Employment: Evidence from the EU Countries
}

\section{Rita Remeikiene ${ }^{1}$, Ligita Gaspareniene ${ }^{2}$, Romualdas Ginevicius ${ }^{3}$, Milan Robin Patak ${ }^{4}$}

1,2 Mykolas Romeris University, Ateities str. 20, 08303 Vilnius, Lithuania, E-mail: rita.remeikiene@mruni.eu; ligitagaspareniene@mruni.eu

${ }^{3}$ Vilnius Gediminas Technical University, Sauletekio av. 11, 10223 Vilnius, Lithuania, E-mail: romualdas.ginevicius@vgtu.lt

${ }^{4}$ University College of Business, Spalena 76/14, 11000 Praha 1, E-mail: patak@vso-praha.eu

\begin{abstract}
: the purpose of this work is to research the links between the unemployment and self-employment rates in the EU member states and provide recommendations on how to manage these links. The results of the empirical study have established that measures to reduce the global unemployment rate, suitable for all EU Member States, cannot be placed on the labor market. Calculations have shown that in the period of 2007-2017, which covered the financial crisis and the upturn, EU countries need to be grouped into specific groups and for each group of countries select appropriate measures to reduce unemployment. The first group of EU countries experienced a "pull" factor effect, the second was the effect of the "push" factor, on unemployment, thus making in the first group of countries more effective self-employment measures to reduce unemployment while the second group of countries - supporting self-employment measures was ineffective in combating unemployment problems.
\end{abstract}

Keywords: self-employment; unemployment; "push" and "pull” factors; EU

\section{Introduction}

The current situation in the European labor market has been significantly affected by a combination of the financial crisis and the crash of the global economy in 2008. From a volatile economic context, observed over the last ten years, the EU labor market has deeply deteriorated: with reference to the data of [1], the unemployment rate in the EU-28 was 0.6 points higher in 2017 than it was in 2007. 
The problem of the high unemployment rate calls for the development of measures that would promote the involvement of the European population into the labor market. One of the main aims defined in the Europe 2020 strategy is to have 75 percent of the active population (aged from 20 to 64) working [2]. Apart from reduction of labor taxation or the support to newly established enterprises (subsidization, exemption from taxes, etc.), promotion of self-employment and atypical forms of employment is also considered to be one of the measures to help to fight unemployment [3].

Although the policy of turning unemployment into self-employment remains an ambiguous issue in economics (a large number of the self-employed is considered as one of the features of developing rather than advanced economies [4], it is still believed that the policy of this kind may significantly increase the probability of a person being employed, raise personal income level and reduce the probability of a person being unemployed [5]. To make the policy of turning unemployment into self-employment successful, it is extremely important to clearly understand the links between unemployment and self-employment.

Previous studies that focused on the dynamic relationship between unemployment and self-employment in different countries provide rather contradictory results: depending on the recession push or entrepreneurial pull approach followed, some authors [6-9] found a positive and statistically significant relationship between the two phenomena under research, while others reported about a negative [10-12] insignificant [13] relationship or the existence of the relationship was not confirmed, especially as far as it concerns particular countries [14].

Unambiguity and inconclusiveness of the results of previous studies, calls for a more comprehensive analysis in this area. The primary purpose of this article is to research the links between the unemployment and self-employment rates in the EU member states and provide the recommendations on how to manage these links. For fulfilment of the defined purpose, the following objectives were raised:

1) Review the literature on the links between unemployment and selfemployment.

2) Select and substantiate the methodology of the research; 3) to introduce the results of the empirical research on the links between unemployment and self-employment in the EU member states and provide the recommendations on how to manage these links.

The methods of the research include systematic and comparative literature review, Spearman's correlation coefficient and multiple regression. 


\section{The Links between Unemployment and Self- Employment: Literature Review}

According to [4], the links between unemployment and self-employment are determined by the structure of employment in a certain country/region and frictions in the labor market. Since it is usually difficult for job seekers to deal with strong labor market frictions, they start treating job search as a relatively less attractive alternative in comparison to self-employment. Minding the fact that much higher unemployment rates and more severe labor market frictions are inherent to developing rather than advanced economies, many authors [15] [16] [17] [4] and others, believe that developing economies have systematically higher self-employment rates than advanced economies. Nevertheless, affected by economic upheavals or industrial declines, advanced economies can also have the challenging periods of the frictions in their labor markets, as it, for instance, could be observed in the EU just after the stroke of the global economic crisis in 2008 . Hence, the models of frictional labor markets have to be adjusted to advanced economies.

Previous studies provide rather inconclusive results on the direction and significance of the links between unemployment and self-employment. The review of previous findings has been presented in Table 1 .

Table 1

The review of previous findings on the links between unemployment and self-employment

\begin{tabular}{|c|c|c|c|}
\hline $\begin{array}{c}\text { Author(-s), } \\
\text { year }\end{array}$ & Research purpose & Research methods & Findings \\
\hline [7] & $\begin{array}{l}\text { To investigate the } \\
\text { dynamic relationship } \\
\text { between self- } \\
\text { employment and } \\
\text { unemployment rates }\end{array}$ & $\begin{array}{l}\text { A two-equation } \\
\text { vector } \\
\text { autoregression } \\
\text { model }\end{array}$ & $\begin{array}{l}\text { The research confirmed } \\
\text { the existence of the } \\
\text { interdependence } \\
\text { between unemployment } \\
\text { and self-employment }\end{array}$ \\
\hline [5] & $\begin{array}{l}\text { To evaluate the } \\
\text { effectiveness of two } \\
\text { self-employed activity } \\
\text { start-up programs for } \\
\text { the unemployed }\end{array}$ & $\begin{array}{l}\text { Administrative data } \\
\text { analysis with a time } \\
\text { lag, survey }\end{array}$ & $\begin{array}{l}\text { Self-employed activity } \\
\text { programs increase the } \\
\text { probability of being } \\
\text { employed, reduce the } \\
\text { probability of being } \\
\text { unemployed and raise } \\
\text { personal income }\end{array}$ \\
\hline [14] & $\begin{array}{l}\text { To provide further time } \\
\text { series evidence on the } \\
\text { links between } \\
\text { unemployment and } \\
\text { self-employment }\end{array}$ & $\begin{array}{l}\text { Autoregressive } \\
\text { Distributed Lag } \\
\text { (ARDL) approach }\end{array}$ & $\begin{array}{l}\text { The empirical results } \\
\text { confirmed existence of } \\
\text { the links between } \\
\text { unemployment and self- } \\
\text { employment in } 7 \text { OECD } \\
\text { countries out of } 28\end{array}$ \\
\hline [4] & $\begin{array}{l}\text { To determine the links } \\
\text { between }\end{array}$ & $\begin{array}{l}\text { Extended standard } \\
\text { DMP search and }\end{array}$ & $\begin{array}{l}\text { Variation in labor } \\
\text { market frictions can }\end{array}$ \\
\hline
\end{tabular}




\begin{tabular}{|c|c|c|c|}
\hline & $\begin{array}{l}\text { employment, } \\
\text { unemployment and } \\
\text { self-employment }\end{array}$ & matching model & $\begin{array}{l}\text { explain almost the entire } \\
\text { variation in both } \\
\text { unemployment and self- } \\
\text { employment, i.e. } \\
\text { unemployment and self- } \\
\text { employment show the } \\
\text { joint variation under the } \\
\text { conditions of the } \\
\text { frictions in the labor } \\
\text { market }\end{array}$ \\
\hline [9] & $\begin{array}{l}\text { To research the long- } \\
\text { term links between } \\
\text { unemployment and } \\
\text { self-employment }\end{array}$ & $\begin{array}{l}\text { Panel cointegration } \\
\text { methods }\end{array}$ & $\begin{array}{l}\text { There exists a positive } \\
\text { and statistically } \\
\text { significant relation } \\
\text { between unemployment } \\
\text { and self-employment }\end{array}$ \\
\hline [6] & $\begin{array}{l}\text { To research the } \\
\text { dynamic relationship } \\
\text { between } \\
\text { unemployment and } \\
\text { self-employment rates }\end{array}$ & $\begin{array}{l}\text { A two-equation } \\
\text { vector } \\
\text { autoregression } \\
\text { model }\end{array}$ & $\begin{array}{l}\text { The research confirmed } \\
\text { the existence of the } \\
\text { interdependence } \\
\text { between unemployment } \\
\text { and self-employment }\end{array}$ \\
\hline [11] & $\begin{array}{l}\text { To research the } \\
\text { dynamic relationship } \\
\text { between } \\
\text { unemployment and } \\
\text { self-employment in } \\
\text { Turkey }\end{array}$ & $\begin{array}{l}\text { Cointegration test, } \\
\text { vector, } \\
\text { correction model }\end{array}$ & $\begin{array}{l}\text { There exists a long-term } \\
\text { relationship between } \\
\text { unemployment and self- } \\
\text { employment }\end{array}$ \\
\hline [12] & $\begin{array}{l}\text { To research the effect } \\
\text { of economic conditions } \\
\text { on self-employment in } \\
\text { Canada }\end{array}$ & $\begin{array}{l}\text { Asynchronous in } \\
\text { variation } \\
\text { economic } \\
\text { conditions across } \\
\text { time and provinces }\end{array}$ & $\begin{array}{l}\text { The relationship } \\
\text { between the provincial } \\
\text { unemployment and self- } \\
\text { employment is negative }\end{array}$ \\
\hline [13] & $\begin{array}{l}\text { To research the links } \\
\text { between } \\
\text { unemployment and } \\
\text { self-employment by } \\
\text { considering the role of } \\
\text { entrepreneurship } \\
\text { training }\end{array}$ & $\begin{array}{l}\text { Survey, regression } \\
\text { models }\end{array}$ & $\begin{array}{l}\text { The results provided } \\
\text { limited support to the } \\
\text { hypothesis } \\
\text { entrepreneurship } \\
\text { training can be effective } \\
\text { in combating } \\
\text { unemployment }\end{array}$ \\
\hline [8] & $\begin{array}{l}\text { To research the links } \\
\text { between } \\
\text { entrepreneurial cycles } \\
\text { and the national } \\
\text { economic cycles }\end{array}$ & $\begin{array}{l}\text { Aggregation, a } \\
\text { panel framework, } \\
\text { Granger causality } \\
\text { test }\end{array}$ & $\begin{array}{l}\text { The entrepreneurial } \\
\text { cycle is positively } \\
\text { affected by the national } \\
\text { unemployment cycle }\end{array}$ \\
\hline
\end{tabular}

Source: compiled by the authors

First of all, it should be noted, that the links between unemployment and selfemployment are analyzed by following "push" and "pull" approaches. The "push" approach, also known as the refugee effect, desperation effect, recession push or unemployment push, affirms that when unemployment rate is rising, an 
increasingly higher number of people start having difficulties in finding paid jobs (or wage jobs), and these difficulties, in their turn, lead to-self-employment as an alternative [11]. Under the conditions of high unemployment rate, the unemployed have lower opportunity costs, which may push them to undertake the risk associated with a business start-up [13]. In this case, unemployment and selfemployment show a positive and statistically significant relationship [6] [7] [8] [9] [4]. The "pull" approach, also known as the prosperity pull or entrepreneurial effect, suggests that since self-employment promotes business activities, it also stimulates a population's inclination to and readiness for entrepreneurial activities, which, in its turn, causes a decline in unemployment in subsequent periods [11] and contributes to the rise of the minimum wage [18-19], i.e. the prosperity pull (or entrepreneurial) effect manifests as the reduction in unemployment rates caused by increasing self-employment. In the latter case, unemployment is negatively related to self-employment [6] [10] [7] [12].

On the basis of one, another or both above-introduced approaches, the majority of literature sources confirm the interdependence between unemployment and selfemployment (as it can be seen in Table 1), although the results of the studies carried out by [6] and [7] disclosed that the "push" effect is considerably stronger than the "pull" effect. These results were confirmed by [11] who found the evidence for the existence of the causality running from self-employment to unemployment rate (i.e. the existence of an entrepreneurial effect was confirmed), but at the same time noted that it was not possible to accurately assess the strength of the entrepreneurial effect due to the involvement of unpaid workers in selfemployment which might plausibly disguise the exact entrepreneurial effect.

It should also be noted that the interdependence between unemployment and selfemployment may vary during the periods of economic (labor market) stability and upheaval. According to [4], the channel of labor market frictions is important since the "variation in labor market frictions can account for a large fraction of the univariate and joint variation in self-employment and unemployment rates across countries observed in the data" (p. 5). In other words, as different countries can be undergoing different periods of an economic (labor market) cycle, they may show different results of the interdependence between unemployment and self-employment. For instance, by employing panel cointegration methods, [9] investigated the COMPENDIA dataset, developed for a wide range of European OECD countries over the period 1990-2011. The results of their study disclosed a positive and statistically significant long-term relation between unemployment and self-employment which was observed in more than half of the countries under consideration. Nevertheless, the relation between unemployment and selfemployment was found to be negative or statistically insignificant for the rest of the countries in the sample, which shows that the relation between the phenomena under research can be bidirectional and depend on the economic (labor market) cycle in a particular country. The differences in the stage of an economic (labor market) cycle in the countries under research may also explain the 
inconclusiveness of the findings of [14] study which confirmed existence of the links between unemployment and self-employment only in 7 out of 28 OECD countries.

In addition, some of the studies revealed that the strength and direction of the interdependence between unemployment and self-employment may depend on some other factors besides the stage of an economic (labor market) cycle. [4] notes the impact of economic policies which determine the flow value of unemployment, the changes in tax-variation caused profitability of own-account work, the enforcement of business size regulations and the size of unemployment benefits (transfers to job seekers reduce the attractiveness of entrepreneurial activities). [20] highlights the impact of demographic factors by stating that the links between unemployment and self-employment can be determined by gender: the authors found that unlike men, women's self-employment decisions were very sensitive to the sources of household income rather than to the general economic conditions.

To summarize, the theoretical recession-push hypothesis suggests a positive, while the prosperity-pull hypothesis proposes a negative relationship between unemployment and self-employment. Due to the involvement of unpaid workers in self-employment which might plausibly disguise the exact entrepreneurial effect, the influence of "push" factors on the relationship between unemployment and self-employment is recognized to be considerably stronger than the influence of "pull" factors. The strength and direction of the links between the two phenomena under research are mainly affected by the stage of an economic (labor market) cycle, which plausibly determines the differences in cross-country findings. Apart from that, some literature sources also confirm the impact of economic policies (the flow value of unemployment, the changes in tax-variation caused profitability of own-account work, the enforcement of business size regulations and the size of unemployment benefits) and demographic factors (gender).

\section{Research Methodology}

To achieve the purpose of the article - a statistically significant relationship between unemployment and self-employment in the EU countries Spearman's Correlation Coefficient (rS) was selected for investigating the strength of the phenomena in terms of legality. The calculations include the unemployment rate, expressed in thousands of individuals (y) and self-employment (x), expressed in thousands of individuals in the EU-28 in the period of 2007-2017.

Spearman's correlation coefficient is a statistical measure of the strength of a monotonic relationship between paired data. In a sample it is denoted by and is by design constrained as follows and its interpretation is similar to that of Pearsons, 
e.g. the closer is to the stronger the monotonic relationship. Correlation is an effect size and so we can verbally describe the strength of the correlation using the following guide for the absolute value of: .00-.19 "very weak"; .20-.39 "weak"; .40-.59 "moderate"; .60-.79 "strong"; .80-1.0 "very strong".

In order to investigate the weight of self-employed people with unemployment rates, is being used the linear multiply regression model. Multiple linear regression attempts to model the relationship between two or more explanatory variables and a response variable by fitting a linear equation to observed data. Every value of the independent variable $x$ is associated with a value of the dependent variable $y$. The population regression line for $p$ explanatory variables $x_{1}, x_{2}, \ldots, x_{\mathrm{p}}$ is defined to be $\mu_{\mathrm{y}}=\beta_{0}+\beta_{1} x_{1}+\beta_{2} x_{2}+\ldots+\beta_{\mathrm{p}} x_{\mathrm{p}}$. This line describes how the mean response $\mu_{\mathrm{y}}$ changes with the explanatory variables. The observed values for $y$ vary about their means $\mu_{\mathrm{y}}$ and are assumed to have the same standard deviation $\sigma$. The fitted values $b_{0}, b_{1}, \ldots, b_{p}$ estimate the parameters $\beta_{0}, \beta_{1}, \ldots, \beta_{\mathrm{p}}$ of the population regression line.

\section{The Results of the Empirical Research}

In the first stage of the empirical study, Spearman's correlation coefficient for the EU-28 countries where Yt is the unemployment rate for the period 2007-2017, Yt1 is the unemployment rate in the last year, $\mathrm{X}$ - self-employed persons, thus, it is possible to classify EU countries in three groups:

1 group. Countries with a negative relationship between the unemployment rate and the level of self-employment, i.e. the unemployment rate reduces the number of self-employed people and vice versa. This group includes countries like: having a very strong connection Greece $\left(r_{S}=-0.939, p=0.000 / s u Y_{t-1}\right)$, Lithuania $\left(r_{S}=-\right.$ $\left.0.927, \mathrm{p}=0.000 / \mathrm{su} \mathrm{Y}_{\mathrm{t}-1}\right)$, Ireland $\left(\mathrm{r}_{\mathrm{S}}=-0.903, \mathrm{p}=0.000 / \mathrm{su} \mathrm{Y}_{\mathrm{t}-1}\right)$, Latvia $\left(\mathrm{r}_{\mathrm{S}}=-\right.$ $0.855, \mathrm{p}=0.002)$, Spain $\left(\mathrm{r}_{\mathrm{S}}=-0.806, \mathrm{p}=0.005\right)$; Italy $\left(\mathrm{r}_{\mathrm{S}}=-0.879, \mathrm{p}=0.002 / \mathrm{su}\right.$ $\left.\mathrm{Y}_{\mathrm{t}-1}\right)$; strong connection Estonia $\left(\mathrm{r}_{\mathrm{S}}=-0.733, \mathrm{p}=0.016\right)$, Cyprus $\left(\mathrm{r}_{\mathrm{S}}=-0.790, \mathrm{p}=\right.$ $\left.0.007 / \mathrm{su} \mathrm{Y}_{\mathrm{t}-1}\right)$, Croatia $\left(\mathrm{r}_{\mathrm{S}}=-0.733, \mathrm{p}=0.016 / \mathrm{su} \mathrm{Y}_{\mathrm{t}-1}\right)$.

Based on "push" and "pull" theories, the 1 group can be classified as pull-based theory, i.e. "pull" factors are those which make the choice of self-employment more attractive to paid employment. For employees who voluntarily leaves the job, there is a greater chance of becoming self-employed. In addition, longer-term unemployment tends to be linked to increased probability of self-employment. Thus, for the first group of countries, only those unemployment reduction measures which are focused on the positive impact that business start-up funding/partial funding has on implementation of ideas, dreams or competences gained at a hired work may serve as the measures of self-employment promotion. This means, the European Commission, in the context of reducing strategic 
unemployment levels, recommends that the assigned countries propose new business development programs in the business cycle recovery/rise phases, because only in this period their return on the efficiency of their use would be highest.

2 group. Countries with a positive relationship between the unemployment rate and the level of self-employment, i.e. the rise in unemployment rates contributes to the growth of self-employment and vice versa. This group includes countries like: having a very strong connection Luxembourg $\left(r_{S}=0.911, p=0.000\right)$, France $\left(r_{S}\right.$ $\left.=0.863, \mathrm{p}=0.01 / \mathrm{su} \mathrm{Y}_{\mathrm{t}-1}\right)$, Netherlands $\left(\mathrm{r}_{\mathrm{S}}=0.842, \mathrm{p}=0.002 / \mathrm{su} \mathrm{Y}_{\mathrm{t}-1}\right) ;$ strong connection Austria $\left(r_{S}=0.721, p=0.019\right)$, Germany $\left(r_{S}=0.758, p=0.011 /\right.$ su $Y_{t}$ $\left.{ }_{1}\right)$, Sweden $\left(r_{\mathrm{S}}=0.614, \mathrm{p}=0.05\right)$ and Belgium $\left(\mathrm{r}_{\mathrm{S}}=0.685, \mathrm{p}=0.01\right)$.

According to [20] "Push" factors are typically those associated with being pushed out of paid employment into a less preferred self-employed situation, and are thus positively associated with increases in the unemployment rate and unemployment durations. The most common "push" set of hypotheses suggests that workers are primarily pushed into self-employment by weak economic job prospects. The 2 group of countries revealed that the population chooses self-employment as a necessity and not as a voluntary choice, while a positive relationship means that as unemployment grows, self-employment also increases, and vice versa. This means, the European Commission in order to reduce the unemployment rate in these countries should not focus on self-employment promotion measures as a way to reduce unemployment.

3 group. Countries that have not recorded statistically significant relationships between unemployment and self-employment (Czech Republic, Denmark, Finland, Hungary, Malta, Poland, Portugal, Romania, Slovakia, Slovenia, UK, Bulgaria).

It can be presumed that the statistically insignificant links cause greater effects of some other labor market factors while solving the problems of unemployment. For instance, sufficient unemployment benefits or corporate taxes discourage from looking for other employment alternatives, such as self-employment [22].

The results of multiple regression evaluated in the second stage of the empirical study are presented in Table 2 .

Table 2

Multiple regression results

\begin{tabular}{|c|c|c|}
\hline Countries & Equation & Explanation \\
\hline \multicolumn{3}{|r|}{1 group $^{*}$} \\
\hline Lithuania & $\begin{array}{l}\text { y } \quad=\quad 577,231- \\
3,098 * \text { Self- } \\
\text { employment }\end{array}$ & $\begin{array}{l}\text { With a decrease of } 1 \text { thousand in self- } \\
\text { employment, the unemployment rate is } \\
\text { increasing by } 3,098 \text { thousand people. }\end{array}$ \\
\hline Ireland & $\begin{array}{l}\text { y }=1,160,443- \\
3,163 * \text { Self- } \\
\text { employment }\end{array}$ & $\begin{array}{l}\text { With a decrease of } 1 \text { thousand in self- } \\
\text { employment, the unemployment rate is } \\
\text { increasing by } 3,163 \text { thousand people. }\end{array}$ \\
\hline
\end{tabular}




\begin{tabular}{|c|c|c|}
\hline Spain & $\begin{array}{l}\text { y }=24,740.714- \\
6.831 * \text { Self- } \\
\text { employment }\end{array}$ & $\begin{array}{l}\text { With a decrease of } 1 \text { thousand in self- } \\
\text { employment, the unemployment rate is } \\
\text { increasing by } 6,831 \text { thousand people. }\end{array}$ \\
\hline Italy & $\begin{array}{l}\text { y }=18,210,727- \\
3,178 * \text { Self- } \\
\text { employment }\end{array}$ & $\begin{array}{l}\text { With a decrease of } 1 \text { thousand in self- } \\
\text { employment, the unemployment rate is } \\
\text { increasing by } 3,178 \text { thousand people. }\end{array}$ \\
\hline Estonia & $\begin{array}{l}\text { y }=262,288- \\
3,836 * \text { Self- } \\
\text { employment }\end{array}$ & $\begin{array}{l}\text { With a decrease in self-employment of } 1 \\
\text { thousand, the unemployment rate increases by } \\
3,836 \text { thousand. individuals. }\end{array}$ \\
\hline Cyprus & $\begin{array}{l}\text { y }=146,885- \\
1,941 * \text { Self- } \\
\text { employment }\end{array}$ & $\begin{array}{l}\text { With a decrease of } 1 \text { thousand in self- } \\
\text { employment, the unemployment rate is } \\
\text { increasing by } 1,941 \text { thousand people. }\end{array}$ \\
\hline Croatia & $\begin{array}{l}\mathrm{y}=1,528,717- \\
0,024 * \text { GDP- } 0,774 * \\
\text { Self-employment }\end{array}$ & $\begin{array}{l}\text { With a decrease of } 1 \text { thousand in self- } \\
\text { employment, the unemployment rate is } \\
\text { increasing by } 774 \text { people. The standardized beta } \\
\text { coefficients showed that the impact of GDP (- } \\
0.764) \text { and self-employment }(-0.643) \text { on the } \\
\text { trends in the unemployment rate are close. }\end{array}$ \\
\hline \multicolumn{3}{|c|}{2 group*. } \\
\hline France & $\begin{array}{l}\text { y }=\text { - } \\
2638,897+1,963 * \text { Self- } \\
\text { employment }\end{array}$ & $\begin{array}{l}\text { With an increase in self-employed employment } \\
\text { of } 1 \text { thousand, the unemployment rate increases } \\
\text { by } 1,963 \text { thousand people. }\end{array}$ \\
\hline Netherlands & $\begin{array}{l}\text { y }=\text { - } \\
465,204+0,822 * \text { Self- } \\
\text { employment }\end{array}$ & $\begin{array}{l}\text { With an increase in self-employed employment } \\
\text { of } 1 \text { thousand, the unemployment rate increases } \\
\text { by } 822 \text { people. }\end{array}$ \\
\hline Belgium & $\begin{array}{l}y=-302,751+1,160^{*} \\
\text { Self-employment }\end{array}$ & $\begin{array}{l}\text { With an increase in self-employed employment } \\
\text { of } 1 \text { thousand, the unemployment rate increases } \\
\text { by } 1,160 \text { thousand people. }\end{array}$ \\
\hline
\end{tabular}

* With regard to Greece, Latvia, Luxembourg, Austria, Germany, Sweden, the multiregression equation self-employment was not statistically significant.

The calculations checked by Multiregresine analysis revealed that country classification or grouping according to certain criteria (in this case "push" and "pull") allows identifying the specifics of countries in combating negative phenomena such as unemployment. 2 group countries are classified as economies in developed countries, which joined the EU in period of 1958 to 1981. Their economy is robust, so the "emission" of the EU-wide unemployment reduction measures into the labor market through the self-employment prism will not be effective and will not reach the target group of unemployed. Meanwhile, Group 1 countries joined the EU in 1981 and later. The economy of these countries is not very stable, therefore the decrease in the autonomy employment significantly increases the number of the unemployed.

\section{Conclusions}

This work represents a preliminary research on the relationship between unemployment and self-employment (positive or negative) between the countries 
and how they become self-employed and illustrates methods to combat unemployment more effectively.

The empirical statistical significance of the relationship between unemployment and the level of self-employment, in all age groups, has revealed that universal measures for reducing unemployment levels that are suitable for all EU members cannot be placed on the labor market. The calculations show that during the period of 2007-2017, which included the financial crisis and the upturn, EU countries need to be grouped into specific groups and for each group of countries select appropriate measures to reduce unemployment.

The first group of countries that includes Greece, Lithuania, Latvia, Estonia, Ireland, Spain, Italy, Cyprus and Croatia, noted the following connections: 1) All joined the EU after 1981 (except Italy), the economy is not as stable as the countries in 2 group, and the statistically significant negative relationship between unemployment and the level of employment ("pull") has been obtained, suggesting that business support programs aimed at a person who has worked for a long period of time in hired work, a short-term unemployed, would more effectively help to reduce unemployment; 2) Countries in 2 group joined the EU before 1981, their economies are stable, as evidenced is their economic development level, and the statistically significant link between unemployment and self-employment levels is positive ("push"). This means, measures aimed at reducing unemployment towards self-employment would increase unemployment, which would result EU funding to reduce the unemployment rate, rather than attaining the strategic objective of reducing unemployment in the EU; 3) In 3 group countries, it would be useful to conduct more in-depth studies on reducing unemployment and to find meaningful links to other, non-self-employed, for example, the relationship between unemployment and the corporate tax rate.

\section{References}

[1] Eurostat, "The EU in the world - labor market" (2018) Retrieved from Internet: $\quad$ https://ec.europa.eu/eurostat/statisticsexplained/index.php/The_EU_in_the_world_-

_labour_market\#Unemployment_rate-

[2] European Commission, "Apie Europos Sajungos politiką. Užimtumas ir socialiniai reikalai. Investavimas ị darbo vietų kūrimą, itrauktị ir socialinę politiką" [About the policies of the EU. Employment and social affairs. Investing in job creation, involvement and social policies] (2014) Retrieved from Internet: https://europa.eu/europeanunion/file/538/download_lt?token=3DFAN1Gb

[3] J. Poor, S. Vinogradov, G. G. Tözsér, I. Antalik, Z., Horbulák, T. Juhász, I. É. Kovács, K. Némethy, R. Machová. “Atypical forms of employment on Hungarian-Slovakian border areas in light of empirical researchers". Acta Polytechnica Hungarica 14 (7), pp. 123-141, 2017 
[4] M. Poschke, "Wage employment, unemployment, and self-employment across countries". International Growth Centre, (2018) Retrieved from Internet: https://www.theigc.org/wp-content/uploads/2018/05/Poschke2018-Working-Paper.pdf

[5] H. J. Baumgartner, M. Caliendo, "Turning unemployment into selfemployment: effectiveness of two start-up programmes", Oxford Bulletin of Economics and Statistics, Vol. 70, No. 3, pp. 347-373, 2008

[6] D. B. Audretsch, D. B., M. A. Carree, R. Thuric, A. van Steel, "Does self-employment reduce unemployment?", CEPR Discussion Paper no. 5057, pp. 1-17, 2005

[7] A. R. Thurik, M. A. Carree, A. van Steel, D. B. Audretsch, "Does selfemployment reduce unemployment?" Journal of Business Venturing, Vol. 23, No. 6, pp. 673-686, 2008, doi: https://doi.org/10.1016/j.jbusvent.2008.01.007

[8] P. D. Koellinger, A. R. Thurik, "Entrepreneurship and the business cycle". The Review of Economics and Statistics, Vol. 94, No. 4, pp. 1143-1156, 2012

[9] G. Saridakis, M. A. Mendoza, R. I. M. Torres, J. Glover, "The relationship between self-employment and unemployment in the long-run: a panel cointegration approach allowing for breaks". Journal of Economic Studies, Vol. 43, No. 3, pp. 358-379, 2016, doi: https://doi.org/10.1108/JES-11-2013-0169

[10] D. Glocker, V. Steiner, "Self-employment: a way to end unemployment? Empirical evidence from German pseudo-panel data". IZA Discussion Paper No. 2561, pp. 1-25, 2007, Retrieved from Internet: http://ftp.iza.org/dp2561.pdf

[11] Y. Ozerkek, F. Dogruel, "Self-employment and unemployment in Turkey". Topics in Middle Eastern and North African Economies, Vol. 17, No. 1, pp. 133-152, 2015, Retrieved from Internet: https://pdfs.semanticscholar.org/129d/bed6e5ef21c54e148c5593fc8b3e48f6 aff6.pdf?_ga=2.148791871.900472165.15390844151907629831.1539084415

[12] C. Pongpaiboon, "The effect of economic conditions on self-employment in Canada". A Thesis Submitted in Partial Fulfilment of the Requirements for the Degree of Bachelor of Arts, Honours in the Department of Economics University of Victoria (2017) Retrieved from Internet: https://www.uvic.ca/socialsciences/economics/assets/docs/honours/Cherry $\%$ 20Pongpaiboon\%20Thesis.pdf

[13] Michaelides, M.; Davis, S. (2016) From unemployment to selfemployment: the role of entrepreneurship training. University of Cyprus, working paper No. 09-2016, Retrieved from Internet: http://papers.econ.ucy.ac.cy/RePEc/papers/09-16.pdf 
[14] F. Halicioglu, S. Yolac, "Testing the impact of unemployment on selfemployment: empirical evidence from OECD countries". MPRA paper No. 65026, 2015, Retrieved from Internet: https://mpra.ub.unimuenchen.de/65026/1/MPRA_paper_65026.pdf

[15] F. Caselli, "Accounting for cross-country income differences". In $P$. Aghion and S. N. Durlauf, eds., 'Handbook of Economic Growth', North Holland, Amsterdam, 2005

[16] D. Gollin, "Nobody's business but my own: self-employment and small enterprise in economic development". Journal of Monetary Economics, Vol. 55, No. 2, pp. 219-233, 2007

[17] S. F. Hipple, "Self-employment in the United States". Monthly Labor Review, Vol. 133, No. 9, pp. 17-32, 2010, https://www.bls.gov/opub/mlr/2010/09/art2full.pdf

[18] C. J. Blattman, S. Dercon, "Occupational choice in early industrializing societies: experimental evidence on the income and health effects of industrial and entrepreneurial work". IZA Discussion Paper No. 10255, pp. 1-91, 2016, Retrieved from: https://www.econstor.eu/bitstream/10419/147941/1/dp10255.pdf

[19] V. Bassi, A. Nansamba, "Information frictions in the labor market: evidence from a field experiment in Uganda", 2017, Retrieved from Internet: http://conference.iza.org/conference_files/GLMLICNetwork_ 2017/bassi_v10212.pdf

[20] A. M. Biehl, T. Gurley-Calvez, B. Hill, "Self-employment of older Americans: do recessions matter?" Small Business Economics, Vol. 42, No. 2, pp. 297-309, 2014

[21] P. S. J. Leonard, J. T. McDonald, J. C. H. Emery, "Push or Pull into Self Employment? Evidence from Longitudinal Canadian Tax Data", 2017, Retrieved from Internet: https://www.unb.ca/fredericton/arts/ nbirdt/_resources/pdfs/working-paper_push-or-pull-into-selfemployment.pdf

[22] A. Zirgulis, T. Šarapovas, "Impact of corporate taxation on unemployment". Journal of Business and Management, Vol. 18, No. 3, pp. 412-426, 2017 